\title{
Integrating Social Resources to Intensify the Vocational Guidance for Literal Arts Students in the College
}

\author{
Wang Yi \\ The director of youth league committee of North China Institute of Science and Technology \\ NCIST \\ Beijing, China \\ 50837364@qq.com
}

\begin{abstract}
Under the circumstances of the current severe employment situation, colleges and universities are confronted with a bigger challenge in the vocational guidance of college students of literal arts. This paper, after analyzing the employment problems involving literal arts students in the college, aims at putting forward approaches to solve this issue effectively. By means of a series of researches, colleges and universities are considered as a major part to bear the responsibility to this phenomenon. They are supposed to improve the vocational guidance of literal arts students in the college, through integrating social resources and strengthening the association and cooperation between families, employers and employment service agencies.
\end{abstract}

Keywords- college students of literal arts; vocational guidance; employment

\section{INTRODUCTION}

Due to differences in majors and social prejudice, college students of literal arts, compared with students of science, have an easier tendency to have the inferiority feelings and to give up self-planning and self-improvement. What's worse, a sense of confusion and frustration occurs frequently when it comes to choosing their careers. This kind of negative mentality leads to the spread of academic nihility mentality and the pessimistic influence that colleges, employers, families and the specialized agencies of the community are connected with each other owing to the students group. As a matter of fact, colleges and universities have a congenital convenience and sufficient resources to conduct the vocational guidance with the help of those social forces, especially the help from vocational guidance committees, employers and families. Colleges and universities should take the initiative to throw an "olive branch ", because it is obvious that they can gain social support and help in the process of vocational guidance.

\section{A Constitution COMBINED WITH FAMILIIES}

The stability of employment and social development concern each family. The central committee of the communist party of China and the state council's policy about reinforcing and improving undergraduates' ideological and political education requires that colleges have to do probe into establishing a communication system and having a close tie with college students' families, which in turn contributes to enhancing students' ideological and political education. In process of achieving the career goal and career success, individuals need to utilize available relationships and forces, among which family is one of the most crucial resources. Either harmonious or conflicted as the relationship between families and individuals is, family ethics, habits, vocational expectations, views and comments exert a profound influence on individuals' development. Additionally, when they are in the dilemma of choosing their careers, family plays a more important role, which can have a great impact on their vocational choices. Also, universities and families ought to work together to draw a clear framework for the students' career planning education. Moreover, they are obliged to help students make clearly their correct standpoints on professionals, lives and selfdevelopment. Meanwhile, it is also a must for them to cooperate with each other to supervise the student vocational planning, enforcement and guidance. From a long-term perspective, schools are able to enrich relatively the parents' knowledge about career planning and help to correct their out-dated viewpoints by means of the approach. What's more, the overall level of families can be largely enhanced by compensating the knowledge defects of vocational planning. With the reasons mentioned above, colleges and universities would work out a united communication system with families. For instance, they can seize the chance when freshmen enroll and take invite their parents to attend a meeting, where the teachers from relevant majors and department leaders introduce to the parents how the vocational guidance gets along and tell their willingness to cooperate with parents. Take another for example, colleges can make full use of the internet platform, such as FeiXin groups, QQ groups, chatting rooms, leaving messages boards, etc to make parents timely informed of the progress of student vocational guidance. Meanwhile, they encourage parents to express their voices openly on school's conducting work.

\section{STRENGTHENING COMMUNICATION AND TIE WITH EMPLOYERS}

\section{A. Appealing for Employing Workers Based on Their Capability so As to get Out of Employment Dilemma.}

At present, there exists a phenomenon that many employers stress too much on engineering and technique 
rather than the liberal arts and humanity, which indicates apparently that they lack correct awareness of genius from the liberal arts filed. Comprehensively observing international high-tech enterprises and their conductors, we note that those companies have already been aware of the profound significance contributed by the top geniuses from the liberal arts field. Vocational guidance need emphasize the importance of genius from the liberal arts field so that the economy in China can go with the tide of world development, and our education can meet the society's needs. Still, it will get students out of the misunderstanding, therefore, it can offer a fairer, opener stage for showing their capabilities. This, unquestionably, provides a new motivation and a better opportunity for the industries to develop faster and better. Hence, to seek a co-development between individual and organization, employers are required to get rid of the employment misunderstanding. Namely, they should learn to select a qualified employee, to a greater extent, to know how to use a talent. Furthermore, universities ought to do research on and set flexible evaluation standards for the liberal arts students, which is aimed at offering qualified staffs needed for employers.

\section{B. Having a Mutually Beneficial and Win-win Cooperation With Employers}

Colleges and universities, on one hand, bear the responsibility of cultivating talents; on the other hand, they have to offer relevant services for employers. Colleges and universities will consider the problems instead of employers and actively seek cooperation, develop the awareness of serving for enterprises and endeavor to found a comprehensive, deepened, closely-connected cooperation relationship. For example, a school of management would follow that associations make a platform, unite with enterprises to benefit all the students. Their concrete ways are as follows: Firstly, enterprises trigger realistic problems. Secondly, associations intrigue students to put the relevant knowledge into working out solutions to solve problems in contests. Finally, enterprises make selections. This framework helps a lot to enhance students' practice capability and strengthen their awareness of innovation and employment. Then, it can mobilize students' activeness and initiative of learning and practicing. Moreover, during the process of organizing, those who have outstanding performances will be employed by the enterprises, following a series of cooperation and cultivation between enterprises and colleges, which realizes mutually benefit and win-win partnership. Besides, colleges and universities also set up an internet conducting platform to form a threeparty communication stage for teachers, the liberal arts students and employers to interact. Websites supply functions and contents like tests with vocational evaluation, planning, online consulting and seeking professions. The liberal art students make full use the internet platform to combine their class learning with off-class self-learning, pay their full attention to problems such as employment policies, industrial culture, interview tips and methods, etc. Meanwhile, it helps gain more chances of practice for the liberal arts students if they make the best of the internet platform where they have on-line communication with excellent alumni and enterprises. To a certain extent, this assists students to accumulate much working experience during college study, to be employed smoothly after graduation. Definitely, there lies a key in school and students as to whether they will succeed or not when they make negotiations with employers. Colleges and universities must spare no efforts to cooperate with public institutions and gain their recognition in an active way.

\section{Selecting Top Enterprises as an Off-campus Internship Base for the Liberal arts}

The move that selecting top enterprises as an off-campus practice base for the liberal arts is an effective way for colleges to offer experience and practice and to enhance their capabilities. The liberal arts students would bear an earlier awareness of the relevance between selfdevelopment and enterprise development by means of joining in the teaching practice in internship base. In this way, they also acquaint themselves with the connections between realizing self-value and contributions for enterprises and society. Hence, they will get correct morals on professions inwardly and place stress on cultivation of professional qualities in the action. This definitely makes a good and solid foundation for their future professional development and reaches the goals to seek individual stability of employment and sustainable development of their careers. The internship bases for teaching and learning are basically divided into two types: campus internship base and off-campus internship base. Preferential policies, even compelled measures by Chinese government have been put forward on the work of setting up off-campus internship bases, but the main source of off-campus internship bases is still the enterprises. On condition that colleges have a mutually beneficial and win-win cooperation with industries, they are probable to realize the aim that liberal arts student cultivation is in accordance with the social development and to require the seamless connection with corporations coming true. Colleges also have a comprehensive observation on the enterprises and positively invite managers, experts and sophisticated employees to take a part in the off-campus teaching and learning practice activity, inspiring colleges to regulate teaching contents such as teaching programs, teaching plans cooperatively. Moreover, they benefit the management of daily teaching practice, the coordination of contradictions commonly among internship students, institutions and the construction of a quality assessment system for the liberal arts students taking off-campus internship. On the other hand, off-campus teaching and learning practice is quite different from the class teaching activity. It not only requires teachers having profound theoretical knowledge, equip themselves with an abundance of practical experience. The quick changes of the enterprises urge the relevant teachers to engage in vocational guidance, have the awareness of broadening the horizon, "Going out, and being able to go out". They should take an active attitude to learn the latest theories and techniques from the enterprises periodically. As well, those with better conditions had better have a close, deep and comprehensive 
cooperation with corporations, concerning manufacturing, the issue of enterprise development and talent selections and cultivation. They give their advices openly on all these problems mentioned above. As far as the enterprises are concerned, it won't cost too much to select top genius from those students who have done the outstanding performances at school. As for colleges, the daily teaching process itself is a broadened way to solve tough employment issues. Therefore, teachers with obligation and responsibility set up a solid bridge between students and enterprises.

\section{STRENGTHENING THE CONNECTION AND COOPERATION BETWEEN EMPLOYMENT SERVICE AGENCIES AND COLLEGES AND UNIVERSITY}

Vocational guidance is a social work, which is limited by schools for liberal arts students. Its smooth conduct is closely related to all the society. In recent years, our personnel, educational and labor departments and their subordinate vocational guidance centers, actively responding to the national employment policies for undergraduates, have adopted many effective measures cooperating with universities, which beneficially improve their own level of service. These service organizations are abundant in resources covering several perspectives of the social-labor market planning, conducting, coordinating, consulting, professional career information and vocational skill appraisal. They offer promptly the necessary legal aids, information resources and expertise supports to college vocational guidance, also offer the relevant services for talent cultivation and employment of universities.

\section{A. Information Guidance}

Colleges can take advantage of information resources from employment service agencies to make up the disadvantage of the literal students' insufficient resources on employment information. Colleges and universities, with the employment service agencies, organize regularly the activities of releasing employment information. Colleges provide student employment intentions for employment service agencies. In turn, employment service agencies offer the latest supplying and demanding information to college students. With help of the employment service agencies, colleges have a feasible screening of information for students, the liberal arts students acting according to the actual circumstances. At the same time, in the process of exposure to the market, colleges find and create specific jobs which are specially designed and suitable for the liberal arts students.

\section{B. Advocating Polices}

Limited by current conditions, the relevant employment promotion and labor contract law isn't popularized in colleges. Meanwhile, unlike those employment agencies with the latest and most representative cases on job market, colleges fail to attract students' attention to studying those laws and regulations. Thus, schools invite staffs from employment service agencies, especially those in the relative departments, to formulate the policies of employment for students. And undoubtedly, it makes the work on interpreting and mastering literatures timely and completely.

\section{Organizing Activities for Vocational Guidance}

Colleges organize vocational guidance activities for liberal arts students which employment service departments are involved in. Activities of vocational guidance speeches, vocational quality assessments, job experiencing and innovation help students understand themselves, the circumstances, experiencing working atmospheres, getting appropriate employment concept and cultivate students with the comprehensive learning concepts, social qualities needed and capabilities in practice. Colleges need a better concern about the quick-responded issue that they should integrate social resources and broaden the liberal arts student employment channels. Colleges are expected to take the initiative to seek cooperation with families, institutions and employment service agencies. It is able to show an overall effect of vocational guidance with the same aim, close cooperation and effective communication. Only in this way can colleges make great progress in vocational guidance designed for the liberal arts students.

\section{REFERRENCES}

[1] Jang Ting. Research on literal arts students' career planning. Nancang university

[2] Yang Linli. Analysis of the employment problem on college students of literal arts in merged university mainly in science and engineering.

[3] Zhang Junsong, Wang Xiaoli, Xu Jialing. Analysis on off-campus practice teaching of vocational education [J]. China's higher education research, , 2004,(07) : 56 57

[4] Chen Rubing. The start of "career guidance into the campus" conducted by Local public employment service agency [N] Beijing talent market .2010-11-13. 